\title{
Ice dynamics and sediment movement: last glacial cycle, Clyde basin, Scotland
}

\author{
Andrew G. FINLAYSON \\ British Geological Survey, Edinburgh, UK \\ E-mail: afin@bgs.ac.uk \\ Institute of Geography, University of Edinburgh, Edinburgh, UK
}

\begin{abstract}
The nature and behaviour of sediment beneath glaciers influences how they flow and respond to changing environmental conditions. The difficulty of accessing the bed of current glaciers is a key constraint to studying the processes involved. This paper explores an alternative approach by relating sediments under the beds of former mid-latitude ice sheets to changing ice behaviour during a glacial cycle. The paper focuses on the partly marine-based Pleistocene British-Irish ice sheet in the Clyde basin, Scotland. A three-dimensional computation of subsurface glacial sediment distribution is derived from 1260 borehole logs. Sediment distribution is linked to an empirically based reconstruction of ice-sheet evolution, permitting identification of distinctive phases of sedimentation. Maximum sediment mobilization and till deposition $\left(\sim 0.04 \mathrm{~m} \mathrm{a}^{-1}\right)$ occurred during ice advance into the basin from adjacent uplands. Transport distances were generally short. Subglacial processes were influenced locally by the relative stiffness of pre-existing sediments, the permeability of the sub-till lithology, and topography; the resulting mean till thickness is $7.7 \mathrm{~m}$ with a high standard deviation of $7.0 \mathrm{~m}$. In places, focused till deposition sealed pre-existing permeable substrates, promoting lower effective pressures. Sediment remobilization by meltwater was a key process as ice margins retreated through the basin.
\end{abstract}

\section{INTRODUCTION}

Patterns of sediment movement beneath soft-bedded glaciers are poorly understood, despite proposed links to glacier dynamics (Alley, 1991; Boulton, 1996; Alley and others, 1997; Clarke, 2005). The original distribution and subsequent redistribution of sediment not only has implications for glacier motion, but also affects the landscape that glaciers override (Nolan and others, 1995; Motyka and others, 2006), producing feedbacks that can influence glacier flow. Despite the success of some recent investigations on present glaciers (Smith and others, 2007), quantifying the volume and style of subglacial sediment mobilization remains a challenge, largely due to inaccessibility of the bed.

The geological record in formerly glaciated landscapes offers an alternative approach. Here landforms and sediments contain a cumulative signature of recent ice-sheet cycles, which enables reconstructions of palaeo-ice-sheet evolution to be made (Boulton and Clark, 1990; Kleman and others, 1997; Stokes and others, 2009). Where formerly glaciated areas have densely spaced borehole datasets, these can be used to compute a three-dimensional (3-D) geological model of glacigenic deposits, allowing their distribution and volumes to be calculated. Combining these geological models with time-transgressive ice-sheet reconstructions makes it possible to reconstruct patterns of sediment mobilization during a glacial cycle - a key aid in understanding glacial sediment transport and deposition mechanisms (Alley, 1991; Boulton, 1996; Alley and others, 1997; Piotrowski and others, 2001; Thomason and Iverson, 2009).

In the Clyde basin, western Scotland (Fig. 1), a wellpreserved landform and sediment record documents the build-up and decay of the last, Main Late Devensian, British-Irish ice sheet (BIIS) (Price, 1975; Rose and Smith, 2008). An extensive database of borehole logs exists for the area (Menzies, 1976, 1981). Consequently, the basin provides an ideal case study to examine both former ice-sheet evolution and sediment mobilization. Finlayson and others (2010) presented a synthesis of geomorphological and stratigraphical evidence from west central Scotland (including the western part of the Clyde basin) (Fig. 1), to derive a conceptual model of ice-sheet advance and decay during the last glacial cycle. The aim of the work reported here is to elucidate the pattern and volume of sediment that was mobilized during the glacial cycle, and examine the implications for the style of sediment transport during different phases of glaciation.

\section{PHYSIOGRAPHIC AND PALAEO-GLACIOLOGICAL SETTING}

The Clyde basin $\left(3173 \mathrm{~km}^{2}\right)$ is a predominantly lowland, formerly glaciated landscape (Fig. 1). It is drained by the river Clyde, which flows in a northwesterly direction for $\sim 120 \mathrm{~km}$, from its source in the Lowther Hills, through the Glasgow conurbation, to reach the coast at the inner Firth of Clyde. Much of the eastern and central basin is underlain by cyclically deposited sedimentary rocks (Scottish Coal Measures Group and Clackmannan Group). These are bounded to the north and west by lavas forming the Kilpatrick Hills, Campsie Fells and Renfrewshire Hills, and to the south by turbidite sequences and lavas, which underlie the fringes of the Southern Uplands. Most of the ground surface is $<250 \mathrm{~m}$ a.s.l., with the surrounding hills rising to $<700 \mathrm{~m}$ a.s.l.

The Clyde basin is first known to have been glaciated $\sim 450$ ka BP; however, earlier episodes of glacier ice advance into the basin may also have occurred (Lee and others, in press). Since then, a further four continental-scale ice-sheet glaciations are thought to have affected the British Isles. The most recent ice sheet overrode the Clyde basin some time after $35 \mathrm{ka}$ BP (Brown and others, 2007; Jacobi and others, 2009). Initial glacier advance was from the northwest, 




Fig. 1. The boundary of the Clyde basin is shown by the red outline. The dashed white rectangle shows the area studied by Finlayson and others (2010). LH: Lowther Hills; RH: Renfrewshire Hills; KH: Kilpatrick Hills; CF: Campsie Fells; RK: river Kelvin. Locations of subsequent figures are shown. Hill-shaded digital surface model built from Intermap Technologies NEXTMap Britain topographic data (NW illumination). Offshore bathymetry from British Geological Survey (BGS) DigBath contours. Inset: Location of Clyde basin within a UK context. The white line gives the approximate extent of last BIIS, based on Bradwell and others (2008) (solid line) and Clark and others (in press) (dashed line).

sourced from an ice cap over the Scottish Highlands; ice flow was then diverted eastwards following the coalescence of Highland and Southern Upland ice masses (Price, 1975; Sutherland and Gordon, 1993. During or soon after maximum glaciation, an ice divide migrated eastward over the Clyde basin, at a time of enhanced drawdown towards western marine outlets of the BIIS (Eyles and McCabe, 1989; Finlayson and others, 2010). Final deglaciation of west central Scotland was characterized, once more, by southeastward and eastward ice flow (a configuration similar to initial ice-sheet advance), prior to complete glacier stagnation. The Clyde basin is thought to have become icefree by $\sim 15 \mathrm{kaBP}$, at which time relative sea level locally approached 40 m a.s.l. (Peacock, 1971, 2003; Rose, 2003).

The regional glacial stratigraphy for the Clyde basin has been well documented (Menzies, 1981; Rose, 1981; Browne and McMillan, 1989; Finlayson and others, 2010). For context, key units relevant to this study are summarized in Table 1. A buried till (older than $35 \mathrm{ka}$ ), the Baillieston Till Formation, has been recorded in parts of northern Glasgow. It is overlain by glaciofluvial gravelly sands derived from a glacier margin positioned near the entrance to the basin (the

Table 1. Stratigraphy of glacigenic sediments in the Clyde basin

\begin{tabular}{|c|c|c|}
\hline Stratigraphic unit & Geological model unit & Main lithologies \\
\hline Clyde Clay Formation & Raised marine deposits & Clay and silt \\
\hline Bellshill Clay Formation & Glaciolacustrine deposits & Clay \\
\hline Broomhouse Sand and Gravel Formation & Glaciofluvial deposits & Sand and gravel \\
\hline Wilderness Till Formation & Till & Diamict \\
\hline Cadder Sand Formation & Buried glaciofluvial deposits & Sand and gravel \\
\hline Baillieston Till Formation & Buried till & Diamict \\
\hline Pre-Quaternary Bedrock & Pre-Quaternary bedrock & Bedrock \\
\hline
\end{tabular}


Cadder Sand Formation), which have yielded woolly rhinoceros bones dated to $35 \mathrm{kacal} \mathrm{BP}$ (Jacobi and others, 2009). Isolated pockets of glaciolacustrine sediments (the Broomhill Clay Formation) also locally overlie the Baillieston Till Formation. All these deposits pre-date the most recent ice-sheet advance into the basin and are predominantly found filling a concealed bedrock valley that trends west-southwest to east-northeast under the floodplain of the river Kelvin (Fig. 1), or in bedrock hollows beneath the river Clyde. Above rests the regional till of the area, the Wilderness Till Formation. In places, the Wilderness Till Formation is overlain by the Broomhouse Sand and Gravel, Bellshill Clay, and Ross Sand formations, these being glaciofluvial, glaciolacustrine and glaciodeltaic deposits, respectively. Raised glaciomarine deposits of the Clyde Clay Formation are found at, or close to, the ground surface across western parts of the basin that lie below 40 ma.s.l.

\section{METHODS}

To determine the pattern of sediment mobilization through the last glacial cycle in the Clyde basin, two sets of information were required: (1) an event stratigraphy, based on geomorphological investigation; and (2) a 3-D geological model that reveals the volume and distribution of glacigenic sediments laid down during particular events or stages.

\section{Geomorphological investigation}

As noted, Finlayson and others (2010) have synthesized evidence from west central Scotland, including the western half of the Clyde basin. In this study, the remainder of the Clyde basin was observed to produce a basin-wide geomorphological dataset to complement the 3-D geological modelling (described below). The glacial geomorphology was investigated using digital surface models (DSMs) and georectifed 1:10000 monoscopic aerial photographs, interrogated within ESRI ArcMap 9.3. The DSMs, built from NEXTMap Britain ${ }^{\text {TM }}$ topographic data $(1.5 \mathrm{~m}$ vertical and $5 \mathrm{~m}$ horizontal resolution), were illuminated from the northwest and northeast in order to limit bias that can be introduced by relief shading (Smith and Clark, 2005) and enable the capture of landforms with different alignments. The DSMs were viewed at several scales, ranging from $1: 10000$ to $1: 200000$, and subsampled at progressively lower horizontal resolutions, from 5 to $50 \mathrm{~m}$, in order to capture both small- and large-scale features. Mapped distributions of glaciomarine, glaciodeltaic, glaciolacustrine and glaciofluvial sediments were based upon a digital $1: 50000$-scale geological map of the whole area (DiGMapGB-50).

\section{3-D geological modelling}

The dimensions and distribution of subsurface glacigenic sediments in the Clyde basin were established using the geological modelling software GSI3D (C)Insight $\mathrm{GmbH}$ ) and $\mathrm{GOCAD}^{\mathrm{TM}}$. In this study, GSI3D (Kessler and others, 2009) was used primarily for development of the model, while GOCAD was used for model interrogation. Input datasets required for the geological modelling process are summarized in Figure 2. Using GSI3D, 85 digital cross sections (total length $1860 \mathrm{~km}$ ) were created at regular $(2-4 \mathrm{~km})$ intervals. These cross sections were constrained by 1260 borehole logs, the 1:50000-scale digital superficial geology map, a digital surface model and a bedrock elevation model. In the
Clyde basin, the bedrock elevation model is based on an extensive borehole dataset with 44753 proven bedrock elevation records; it is also 'influenced' by a further 7028 total-depth (bedrock not reached) records (Lawley and Garcia-Bajo, 2009). Collectively, the 85 cross sections formed a 'fence diagram', which was combined with the digital geological map of the basin to create envelopes, representing the lateral (surface and buried) extent of model units (Table 1). Triangulated irregular networks (TINs) were then computed for the surface and base of each unit in GSI3D, by interpolating between regularly spaced $x, y, z$ nodes on the cross sections and envelopes using an incremental Delaunay triangulation algorithm (Green and Sibson, 1978).

The borehole $\log$ and location files, used in the cross sections, were imported from a nationwide database, which includes geotechnical site investigation logs, water well records, sand and gravel assessment reports and coalfield investigations. Because the original focus of each data subset was different, the detail concerning the glacigenic deposits is variable. Consequently, during selection of the 1260 boreholes used for the geological modelling, preference was given to those that described the glacigenic deposits in most detail and those that penetrated the full thickness of the glacigenic deposits. Data-handling limitations and variable borehole record quality precluded use of the full $50000+$ borehole dataset for the geological modelling. Care was taken to ensure that selected boreholes were from sites evenly distributed throughout the model area. The only 'holes' in the borehole data are where bedrock is present at the land surface. However, since these sites lie outside the envelopes created for model units, they did not affect the calculation.

A requirement of the GSI3D program is that the geological model adheres to an assigned stratigraphy. The stratigraphy used here (Table 1) is a simplification of the stratigraphy developed by Browne and McMillan (1989), and is consistent with that given by Menzies (1981). Due to the scale of the study area, 'till' was treated as a homogeneous unit. The Wilderness Till Formation has been described as a deformation till (Rose and others, 1988) and predominantly comprises a massive matrix-supported diamict. However, lenses of sand and gravel, tectonized sorted sediments and till stratification have also been observed (Menzies, 1981; Browne and McMillan, 1989). These till heterogeneities were too small-scale to be included in the present basin-wide study, although they are a focus of ongoing work within the Glasgow conurbation using densely spaced geotechnical data and geostatistical analyses (Kearsey and others, 2011).

\section{RESULTS AND DISCUSSION}

\section{The geomorphology of the Clyde basin}

A prerequisite for interpretation of the 3-D geological modelling results is an event stratigraphy, based here on geomorphological data. Results of the geomorphological investigation (Fig. 3) and the interpreted event stratigraphy are given below. Note that data for the western part of the basin have been published previously (Finlayson and others, 2010) (Fig. 1), and that new mapping encompasses the remainder of the basin. However, for clarity the basin as a whole is summarized. 


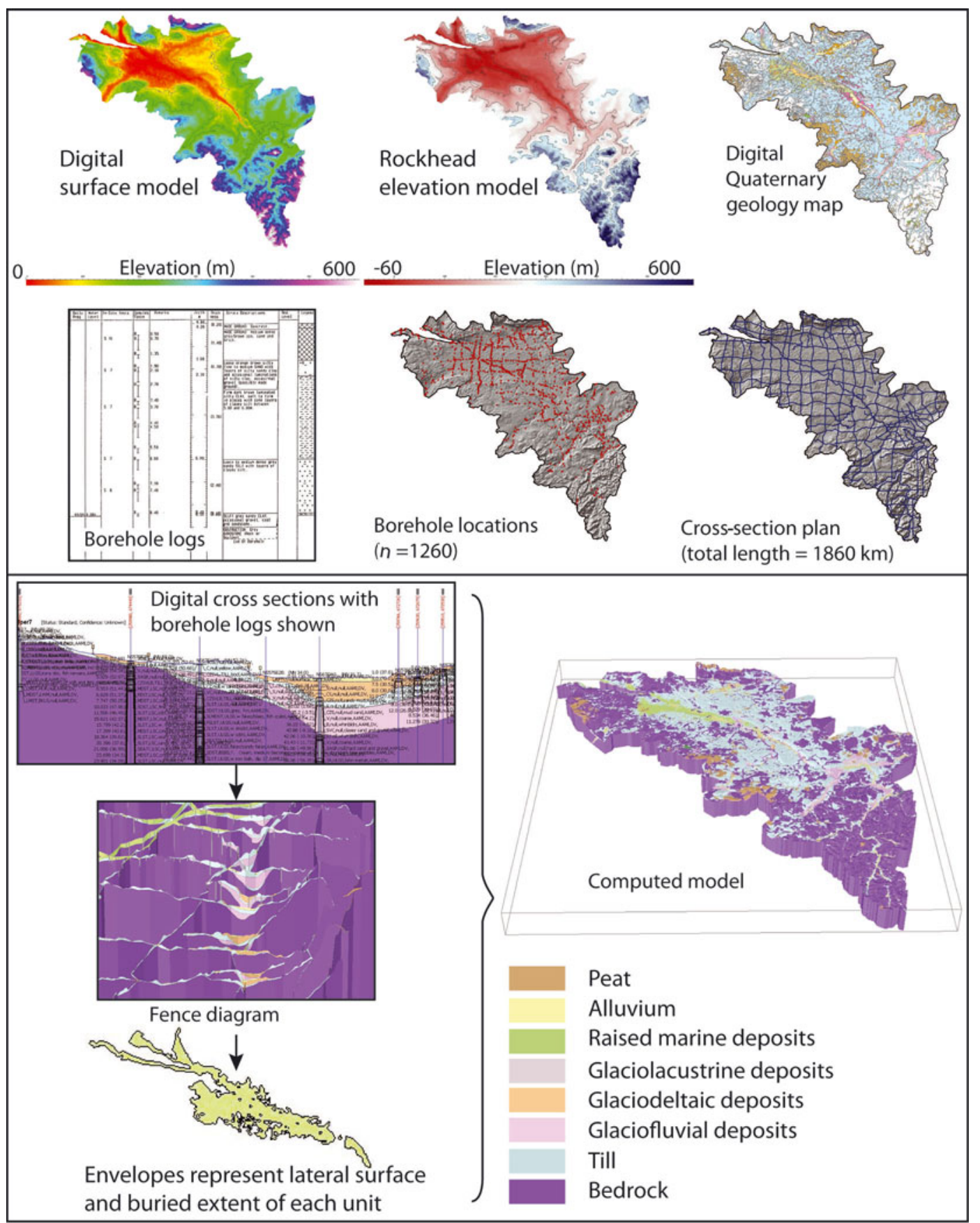

Fig. 2. Upper box: input datasets required for the 3-D geological modelling. Lower box: summary of workflow.

\section{Description}

The northwestern part of the basin is dominated by a land system of drumlins and ribbed moraine over the low ground (underlain by sedimentary rocks). There is little sediment cover over the volcanic rocks forming the higher ground, where numerous striations have been recorded (Paterson and others, 1998). The drumlinized land system is overlain by glaciodeltaic sequences in parts of the Kelvin Valley, and by raised glaciomarine sediments in the Glasgow area. The southeastern part of the Clyde basin is characterized by glaciofluvial deposits (including eskers) and by meltwater channels.

Drumlins in the Clyde basin possess differing alignments (Fig. 3), as previously noted by Rose and Letzer (1977) and Rose and Smith (2008). Individual flow sets (Boulton and Clark, 1990; Kleman and others, 2006; Stokes and others
2009), inferred from drumlin alignment, are shown for the Clyde basin in Figure 4a. The relative age of each flow set is based on landform overprinting (e.g. Fig. 4b) (Hughes and others, 2010), and stratigraphical evidence synthesized from sites across west central Scotland (Finlayson and others, 2010). As expected, drumlin morphological characteristics are consistent with those observed for British drumlins by Clark and others (2009). The range of drumlin lengths, widths and elongation, and their relationships, are shown as a plot of co-variation in Figure 5, following the approach of Clark and others (2009).

In the Clyde basin (and Ayrshire basin to the south), ribbed moraine, where present, always appear to be overprinted by drumlins - a pattern also apparent in the subglacial bedform map of Hughes and others (2010). Finlayson and others (2010) suggested that some of this 


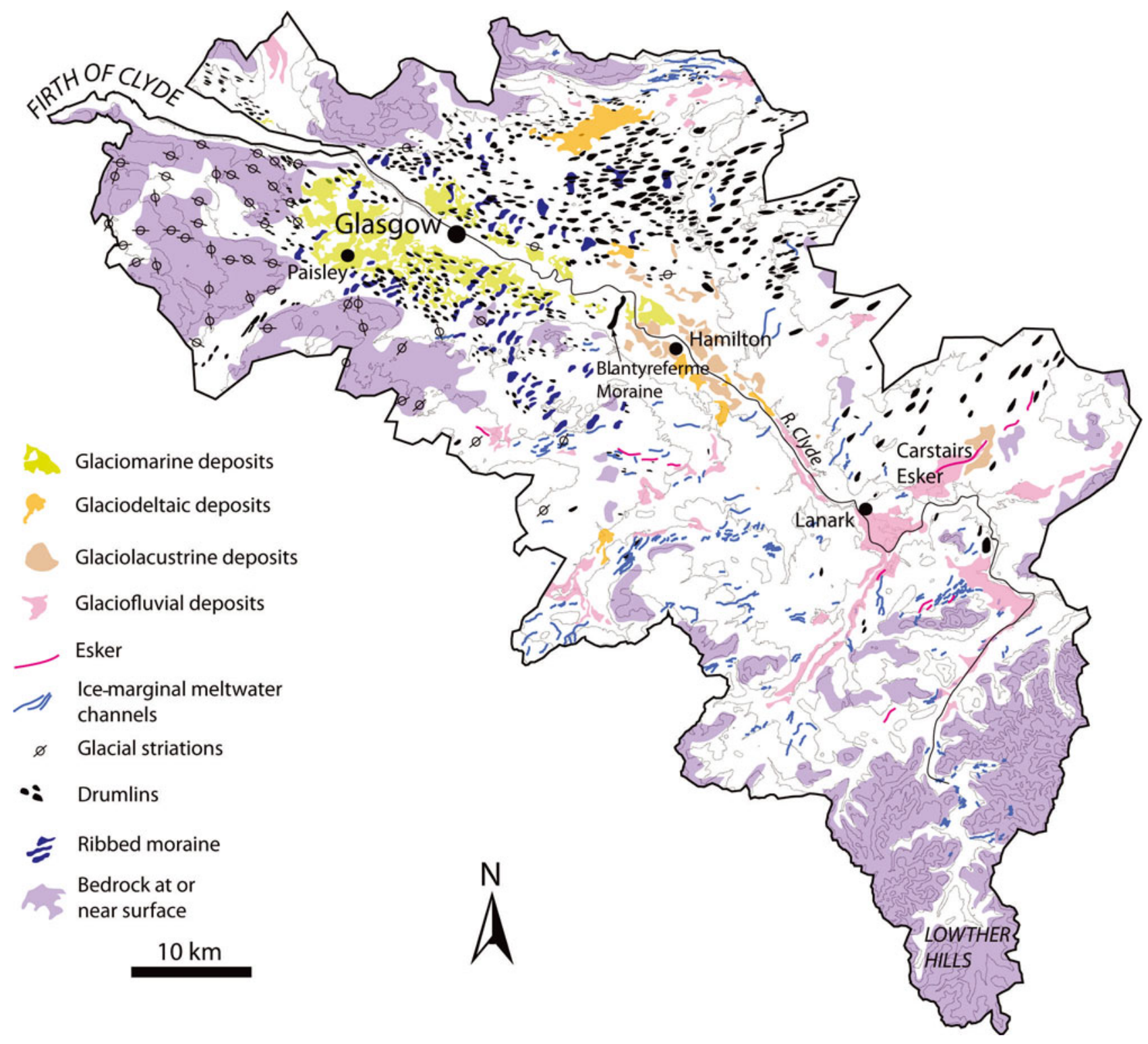

Fig. 3. Geomorphology and glacial geology of the Clyde basin. Glacial striations taken from Paterson and others (1998).

ribbed moraine may have initiated as ice-marginal sediment ridges, generated by folding and thrusting of thick sequences of proglacial sediments, during ice-sheet advance into the basin from the northwest. There is sedimentological evidence that supports this, where till overlies a low ridge of glaciotectonically thrusted silts, sands and gravels (McMillan and Browne, 1983). These landforms tend to be present only in the lower Clyde basin, where a number of the factors considered important for genesis of glaciotectonic phenomena (Aber and others, 1989) were likely to have operated (e.g. ice advance against topography, damming of proglacial lakes).

The ice-marginal landforms, including meltwater channels, glaciodeltaic deposits, glaciolacustrine deposits and moraines, reveal stages of ice-margin retreat (Clark and others, in press), shown in Figure 6. A zone of ice-cap separation is inferred across the southern part of the basin in the vicinity of the Carstairs esker (Fig. 3). This supports the suggestion of Thomas and Montague (1997) that the esker system developed in an interlobate sediment sink, during uncoupling of northern- and southern-sourced ice caps. Similar persistent subglacial conduits have been observed in modern glacial environments, separating the behaviour of confluent ice masses (Benn and others, 2009). Aside from minor differences in ice-margin detail, the overall pattern of glacier retreat inferred here supports that presented by Clark and others (in press).

\section{Interpretation: an event stratigraphy}

Combining the geomorphological evidence with recently published reconstructions for adjacent parts of the last BIIS allows an event stratigraphy to be proposed for the Clyde basin (Fig. 7). Initial ice-sheet advance into the Clyde basin was from the northwest (Fig. 7a) some time after $35 \mathrm{ka} \mathrm{BP}$ (Jacobi and others, 2009). The configuration (Fig. 7a) would have permitted the build-up of an ice-dammed lake by blocking the river Clyde (Price, 1975). The buried glaciolacustrine (Broomhill Clay Formation) sediments (Table 1) may be remnant deposits from this lake. In the Kelvin Valley, outwash sediments of the Cadder Sand and Gravel Formation were overridden during glacier advance.

An ice dome developed over the Southern Uplands, and coalesced with Highland-sourced ice to form an ice divide to the west of the Clyde basin, forcing flow towards the 


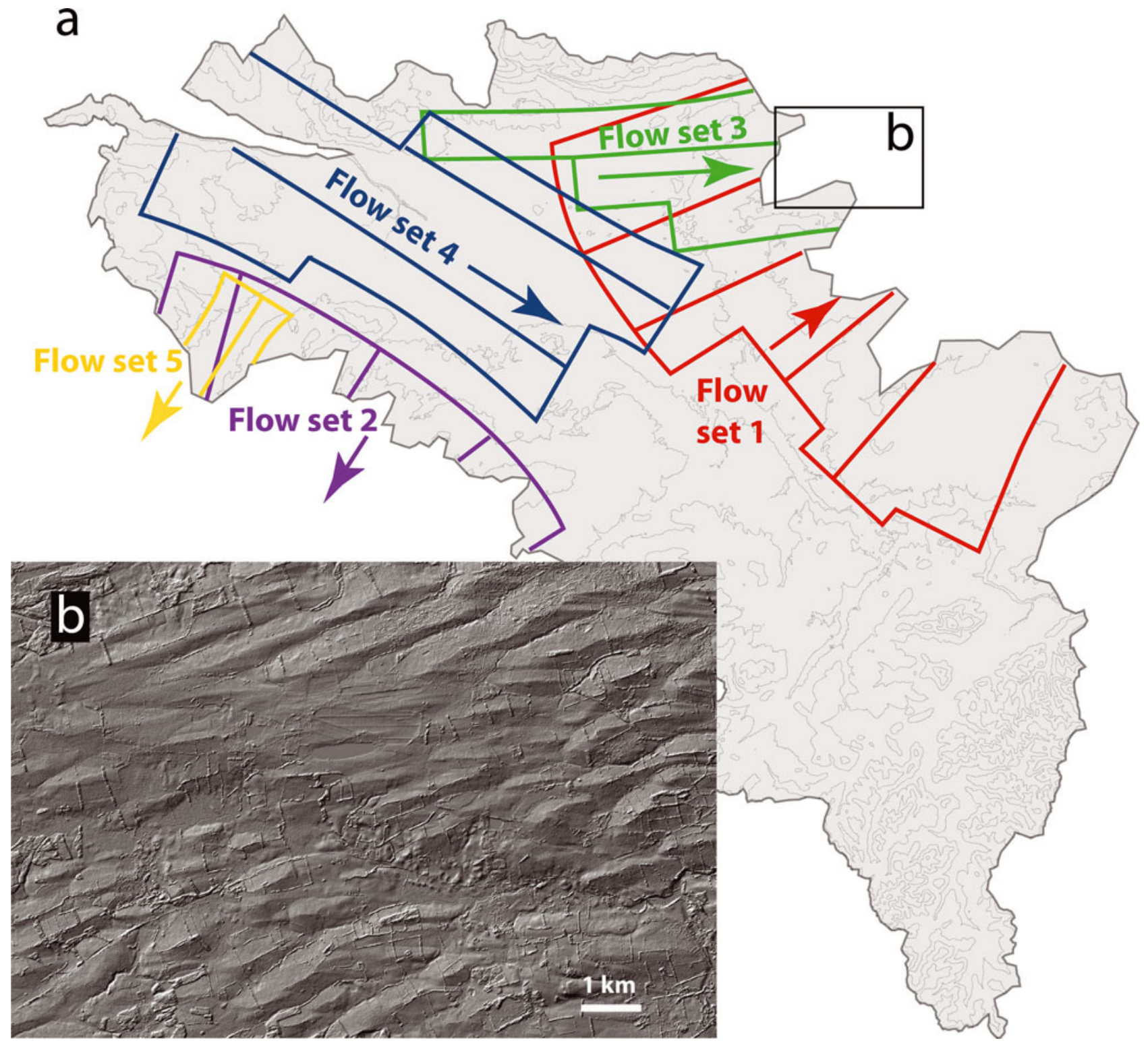

Fig. 4. (a) Flow sets inferred from drumlin alignment in the Clyde basin. (b) Interference pattern developed immediately to the east of the Clyde basin. Here northeasterly-oriented drumlins of flow set 1 are overprinted by easterly-oriented drumlins of flow set 3 . Hill-shaded digital surface model built from Intermap Technologies NEXTMap Britain topographic data.

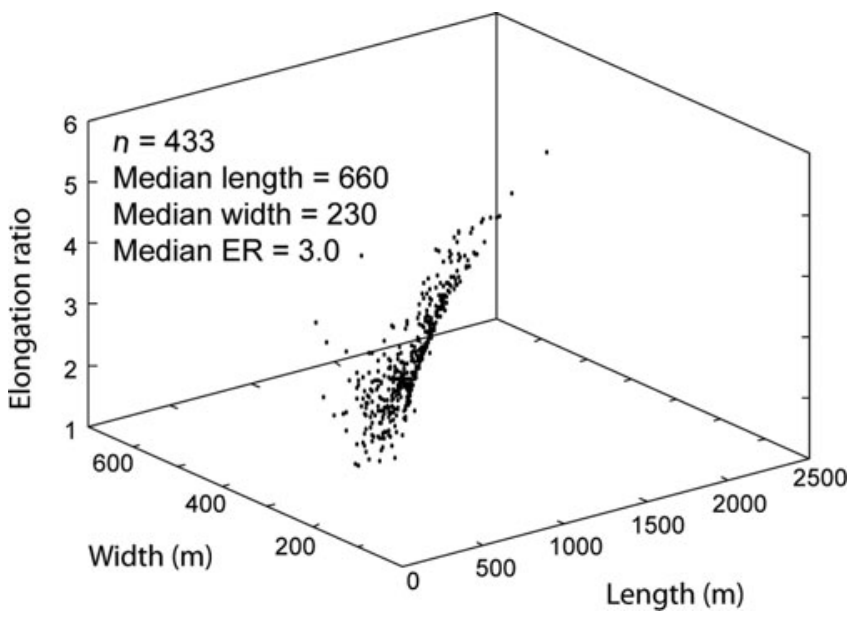

Fig. 5. Covariation plot of Clyde basin drumlin characteristics. The scale-dependent elongation limit, first recognized for drumlins by Clark and others (2009), can be seen. northeast (Fig. 7b). The drumlins of flow set 1 probably initiated at that time. This configuration may have broadly persisted until the BIIS approached its maximum extent, around $27 \mathrm{ka} \mathrm{BP}$ (Clark and others, in press). Enhanced drawdown towards western marine outlets (Eyles and McCabe, 1989; Scourse and others, 2009; Dunlop and others, 2010) then forced the ice divide to migrate over the Clyde basin (Fig. 7c). Flow set 2 may have begun to develop during, or following, this phase; it is not possible to establish if flow set 3 also began to form at that time, or later. In general the geomorphological signature of this stage (Fig. 7c) is limited in the Clyde basin. However, westerly and southwesterly flow left a strong imprint in the Ayrshire basin to the southwest (Finlayson and others, 2010). The presence of an ice divide over the Clyde basin, with associated low or zero velocities, favoured preservation of subglacial bedforms left during the earlier part of the glacial cycle (Clark, 1993).

During ice-sheet decay (Fig. 7d), ice flow in the lower Clyde basin was from the northwest, documented by flow 


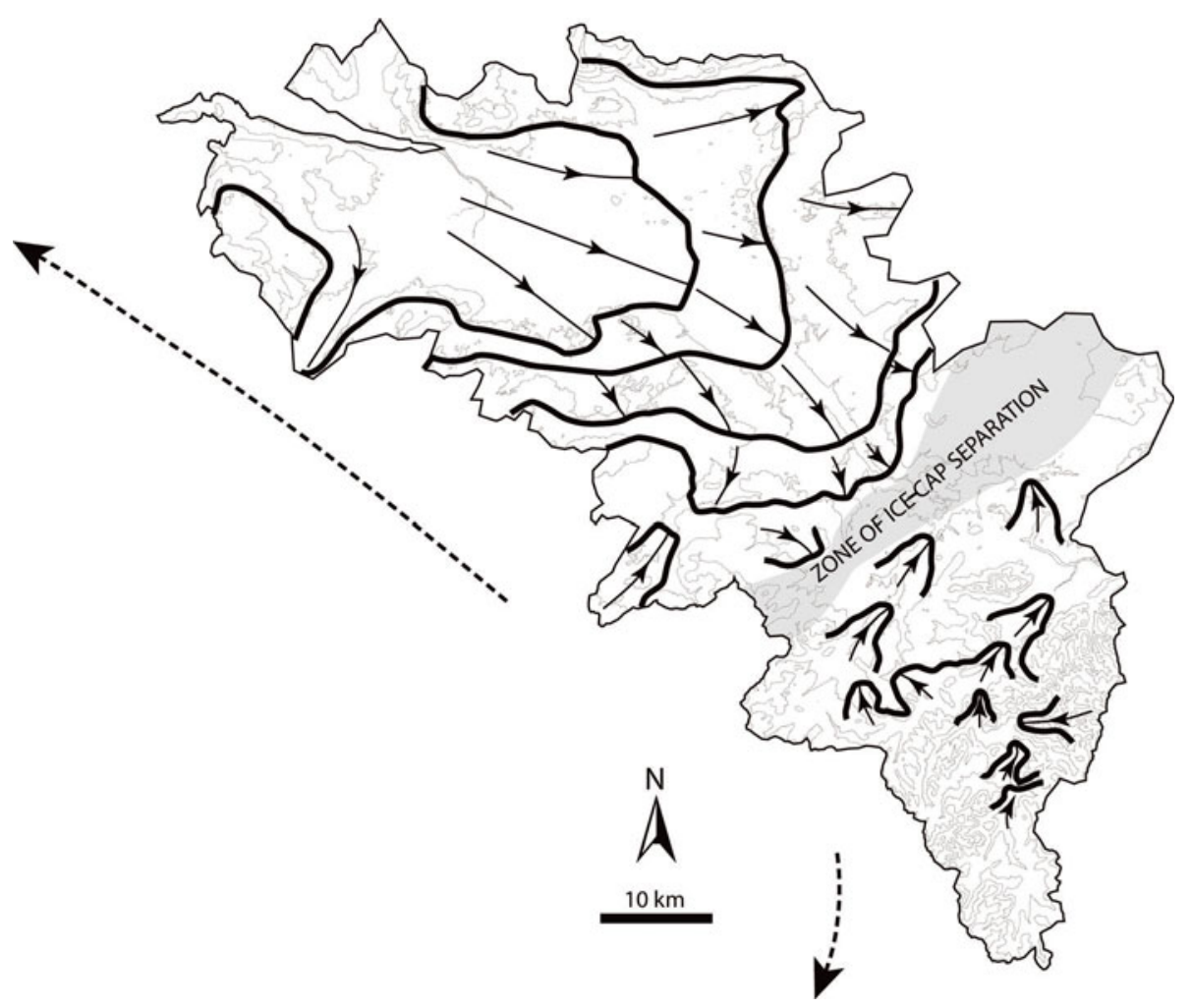

Fig. 6. Suggested pattern of ice-cap separation and subsequent retreat, interpreted from ice-marginal landforms (e.g. meltwater channels, ice-dammed lake deposits, moraines). Black arrows denote ice-flow direction. Dashed line shows retreat direction.

set 4. A zone of separation developed between the northernsourced ice and ice caps centred over the Southern Uplands (Fig. 6) (Thomas and Montague, 1997). Glaciofluvial sand and gravel deposits, and glaciolacustrine deposits, were focused along this corridor (Fig. 3). The latter stages of deglaciation in the Clyde basin (Fig. 7e) were accompanied by the deposition of lacustrine and deltaic sediment into 'Lake Clydesdale', which was dammed by an ice margin positioned at the Blantyreferme moraine (Bell, 1874) (Fig. 3). Drumlins of flow set 4 probably continued to form at this stage, as well as those belonging to flow set 5 . Final retreat of Highland-sourced ice in the Clyde basin was accompanied by invasion of the contemporary sea, in which glaciomarine sediments were deposited up to $40 \mathrm{~m}$ a.s.l. (Browne and McMillan, 1990).

\section{3-D geological modelling results}

The computed model of glacigenic deposits (total volume $9.75 \mathrm{~km}^{3}$ ) in the Clyde basin is shown in Figure 8 . Volumes of individual units are given in Table 2, and modelled thicknesses of example units are shown in Figure 9. The buried till and buried glaciofluvial deposits are generally restricted to the concealed bedrock valley under the floodplain of modern river Kelvin. Here they exceed $40 \mathrm{~m}$ in thickness (Fig. 9). Buried glaciofluvial deposits are also present in concealed channels in the upper Clyde basin. Buried glaciolacustrine deposits are restricted in extent, only occurring as isolated pockets under the river Clyde.

There is only one bulk till unit across much of the basin; it accounts for $\sim 70 \%$ of the total sediment in the basin. Variations in till thickness are apparent, ranging from $0.01 \mathrm{~m}$ to $>40 \mathrm{~m}$ (Fig. 9). Median and mean modelled till thickness are 5.8 and $7.7 \mathrm{~m}$, respectively (standard deviation 7.0 ).
These values are consistent with the $6 \mathrm{~m}$ mean thickness calculated by Menzies (1981) for till in central Glasgow. Till is generally thin (or absent) around the margin of the basin (Fig. 9). The thickest till sequences are developed over the buried glaciofluvial deposits (Fig. 10), which are more permeable than the surrounding sedimentary rocks. The presence of thick till over these glaciofluvial gravelly sands supports suggestions elsewhere that efficient sub-till drainage can cause dewatering and stiffening of subglacially mobilized sediments, thereby promoting deposition (Boulton and others, 2001; Meranio and Eyles, 2009). However, the distribution of thick till probably also partially reflects infilling of the pre-existing topography (Boyce and Eyles, 2000), since the buried glaciofluvial deposits tend to be preserved in bedrock depressions. Assuming the buried

Table 2. Computed volumes of glacigenic sediments in the Clyde basin

\begin{tabular}{lcc}
\hline Geological model unit & $\begin{array}{c}\text { Area } \\
\mathrm{km}^{2}\end{array}$ & $\begin{array}{c}\text { Volume } \\
\mathrm{km}^{3}\end{array}$ \\
\hline Raised marine deposits & 160.86 & 1.29 \\
Glaciodeltaic deposits & 22.74 & 0.09 \\
Glaciolacustrine deposits & 72.39 & 0.32 \\
Glaciofluvial deposits & 140 & 0.67 \\
Till & 2259 & 7.2 \\
Buried glaciolacustrine deposits & 1.84 & 0.0038 \\
Buried glaciofluvial deposits & 32.7 & 0.15 \\
Buried till & 8.67 & 0.03 \\
Total & & 9.7538 \\
\hline
\end{tabular}




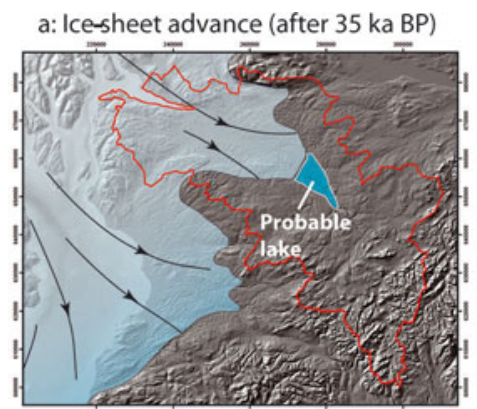

b: Late Devensian glaciation ( 30-25 ka BP)

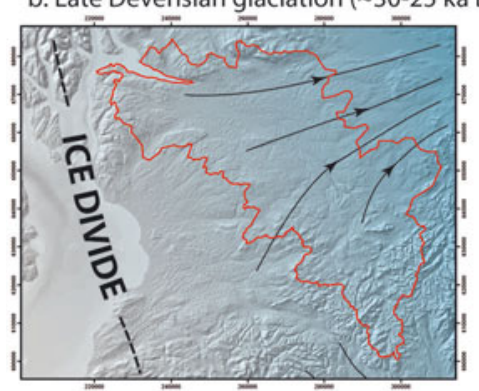

c: Late Devensian glaciation ( 25-20 ka BP

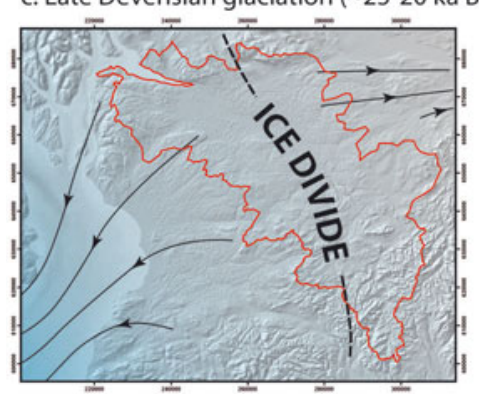

d: Ice-cap uncoupling (before $15 \mathrm{ka} \mathrm{BP}$ )
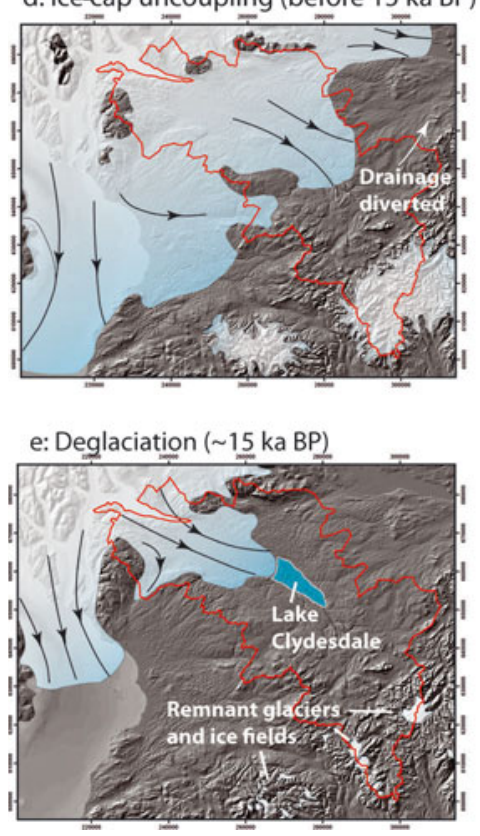

Fig. 7. Reconstructed stages showing the evolution of the last BIIS in the Clyde basin. (a) Advance of outlet glacier into the Clyde basin, accompanied by lake ponding. (b) Development of ice divide to the west of the Clyde basin, accompanied by ice flow to the northeast. (c) Migration of ice divide over the Clyde basin. (d) Ice-divide migration to northwest, ice-sheet decay and separation into ice caps. (e) Final glacier retreat in Clyde basin, accompanied by the ponding of 'Lake Clydesdale'. Hill-shaded digital surface model built from Intermap Technologies NEXTMap Britain topographic data (NW illumination). glaciofluvial deposits are correlative with the Cadder Sands and Gravel Formation (Table 1), the overlying till package in those areas can be considered wholly a product of the last glacial cycle. Figure 11 shows an example of one such till package, which overlies the largest deposit of buried glaciofluvial sediments in the Kelvin Valley. Here a net volume of $0.62 \mathrm{~km}^{3}$ was deposited over $32 \mathrm{~km}^{2}$. Thick till is also present in an area immediately down-ice from zones likely to have been occupied, initially, by soft deformable sediment during ice-sheet advance (see below).

Glaciofluvial, glaciodeltaic and glaciolacustrine deposits are widespread alongside drainage pathways in the Clyde basin where they reach up to $20 \mathrm{~m}$ thickness in places (Fig. 9). Collectively, these deposits represent $11 \%$ of the total sediment volume in the basin. The raised marine deposits in the lower Clyde basin provide the second largest contribution (13\%) to the total basin sediment volume; these sediments exceed $20 \mathrm{~m}$ thickness along pre-existing topographic lows.

\section{Sediment mobilization during the last glacial cycle}

Using the event stratigraphy (Fig. 7) and the geological modelling results, progress can be made towards a basinscale reconstruction of sediment mobilization during the last glacial cycle.

\section{Ice-sheet advance (Fig. 7a)}

It has been theorized that ice-sheet advance is a key phase of till deposition (Boulton, 1996). The preservation of sediments and bedforms interpreted to have begun formation during, or following, this initial stage of the glacial cycle (ribbed moraine and flow set 1 drumlins) does indeed suggest that a significant volume of till had been deposited during the ice-sheet advance phase. Sediment within drumlins is often found to pre-date the drumlin-forming event (Knight and McCabe, 1997; Stokes and others, 2011). If this is also true for the Clyde basin drumlins, it supports a case for an early phase of till deposition. The till package that rests on the buried fluvial deposits (Fig. 11) in the Kelvin Valley is considered to have been deposited during the last glacial cycle (see above). Here $0.62 \mathrm{~km}^{3}$ of till has been deposited over $31 \mathrm{~km}^{2}$, which equates to a uniform net deposition rate through the glacial cycle ( $\sim 35 \mathrm{ka}$ BP to $\sim 15 \mathrm{ka}$ BP) of $0.001 \mathrm{~m} \mathrm{a}^{-1}\left(\right.$ or m$^{3} \mathrm{~m}^{-2} \mathrm{a}^{-1}$ ). However, if much of that till package was deposited during advance through the basin (this could have occurred over as little as $\sim 0.5 \mathrm{ka}$, according to the recent BIIS simulation of Hubbard and others (2009)), which is a prerequisite for drumlins to have formed in those sediments, reconstructed net deposition increases to $\sim 0.04 \mathrm{~m} \mathrm{a}^{-1}$. These till deposition rates are only slightly higher than those proposed for ice-marginal zones by Boulton (1996) and are of a similar order of magnitude to rates of subglacial till deposition considered by Sugden and John (1976), but they assume no latter erosion. This assumption can be partially justified here on two accounts: the Clyde basin was subsequently positioned close to, or under, an ice divide during maximum glaciation (Fig. $7 \mathrm{~b}$ and c; Finlayson and others, 2010), where minimal erosion would have been expected (Boulton, 1996); and bedforms interpreted to have formed during early ice-flow stages are preserved. It should be noted that these till accumulation rates cannot be used to estimate bedrock erosion, since a significant fraction is likely to have derived from remobilized sediment (discussed below). 


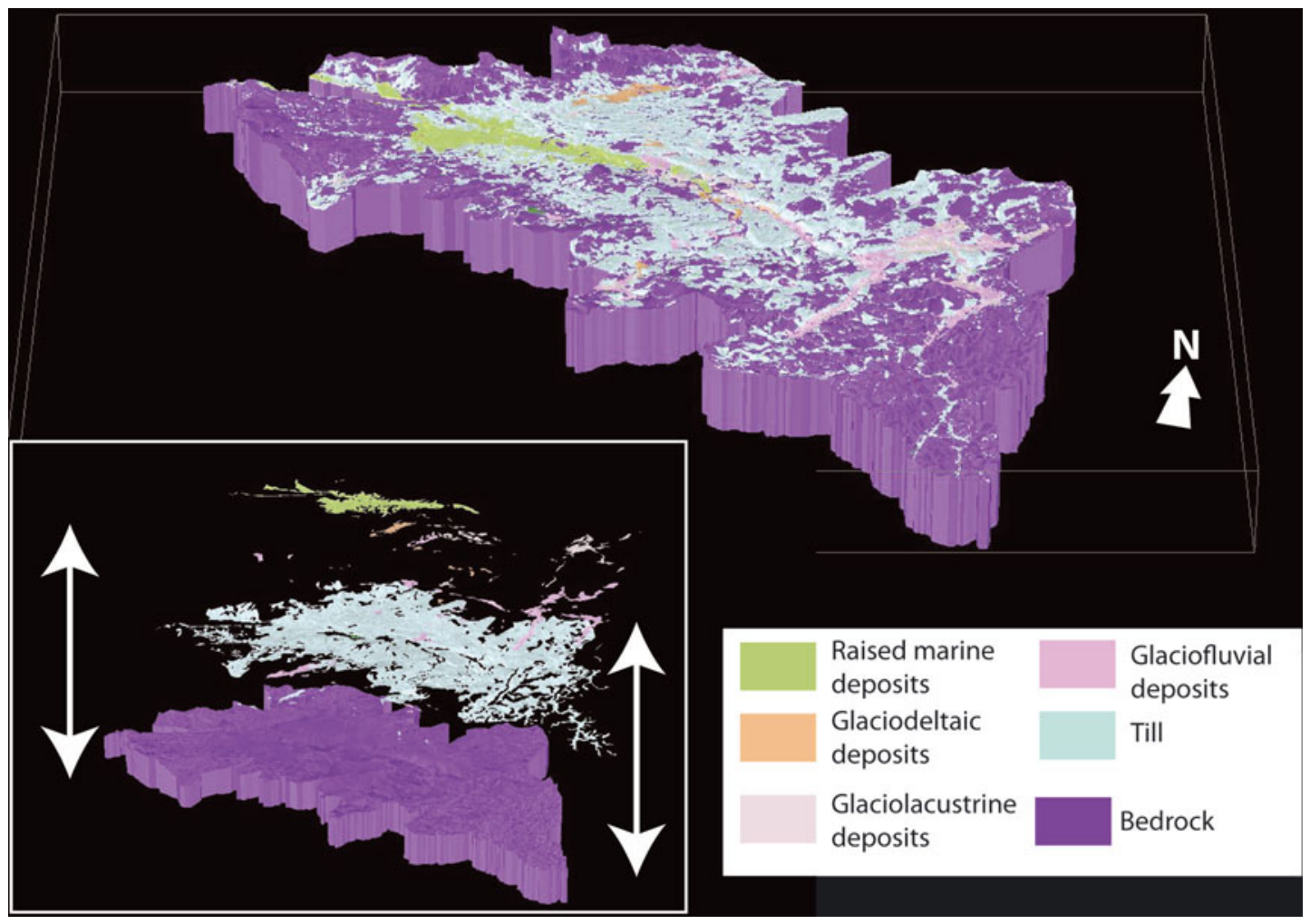

Fig. 8. Computed geological model showing glacigenic deposits in the Clyde basin. Inset: geological model is vertically separated to show individual sediment packages.

It is clear, however, that till deposition during advance was not uniform across the basin; the $\sim 20 \mathrm{~m}$ thickness of till described above, in the Kelvin Valley, is not reproduced everywhere (Fig. 9). Preconditioning factors may therefore have influenced till accumulation. It is notable that no marine deposits and few glaciolacustrine deposits are revealed below till in the model. However, conditions prior to ice-sheet build-up indicate that such deposits were likely to have been locally extensive: global sea level was at least $6.6 \mathrm{~m}$ higher during the Last Interglacial (marine isotope stage (MIS) 5e; Kopp and others, 2009) and relative sea level was probably higher during the prior continental-scale ice-sheet deglaciation (MIS 6); ice-dammed lakes are also likely to have accompanied ice-sheet build-up by blocking the river Clyde (Price, 1975). Reworking of these deposits probably formed the bulk of till that accumulated during ice-sheet advance (e.g. Ó Cofaigh and others, 2011); indeed lenses of folded laminated sediments have been observed in till in the Glasgow area (Menzies, 1981). The presence of the thickest till packages in the vicinity of, or immediately down-ice from, modern marine and glaciolacustrine sediments (Figs 3 and 9) lends support to the idea that similar sediments were previously a key source for till deposited during advance. Where ice-sheet advance was into relatively soft, water-saturated sediments (e.g. glaciomarine, glaciolacustrine or deltaic deposits), deformation probably ensued as plug flow (Leysinger Vieli and Gudmundsson, 2010). Sediment removal up-glacier, may have been in excess of $20 \mathrm{~m}$, based on the thickness of raised marine deposits presently occupying the Clyde basin. Subsequent deposition of thick till then occurred when glaciotectonic stress (lateral stress + shear stress: Aber and others, 1989) fell below sediment strength, possibly through sediment dewatering as it moved over more permeable (buried glaciofluvial deposits) material, or as the ice margin passed over, leading to a reduction in glaciotectonic stress. The result is that overall transport distances were relatively short, consistent with the limited down-ice distribution of thick till sequences and the preservation of some sedimentary structures locally within the till. Where ice advanced over stiffer pre-existing till, overriding or mixed flow (Leysinger Vieli and Gudmundsson, 2010) was more likely, with reduced basal sediment mobilization and reduced accumulation of 'new' till. A switch to these conditions would also have taken place in zones previously characterized by plug flow, once the supply of relatively soft sediments became exhausted, otherwise the thick till wedge would have migrated down-glacier with the advancing ice front. Thus, spatial variations in sediment mobilization by deformation were probably governed by the relative stiffness of pre-existing substrate, with implications for the glacier flow mechanism.

A result of geological modelling, and previous stratigraphical work in the Glasgow area (Menzies, 1981; Browne and McMillan, 1989) is that, with the exception of those restricted locations where buried till packages are identified (Fig. 9), only one main till layer (median thickness $5.6 \mathrm{~m}$ ) is present in the basin. It is extremely unlikely that the $\sim 7 \mathrm{~km}^{3}$ of till forming that layer is wholly a deposit from the last glacial cycle. To generate that volume of till again would require $\sim 3$ times the volume of all other sediments presently available in the basin for reworking. Given the topographically confined (by Clyde Plateau Volcanic Formation) northwestern entrance to the basin, which has little or no till cover (Fig. 9), transport of the remaining volume of till into the basin via a continuous deforming bed is not probable. It is more likely that till from previous glaciations remained in the basin and was, to an extent, reused by the next. 

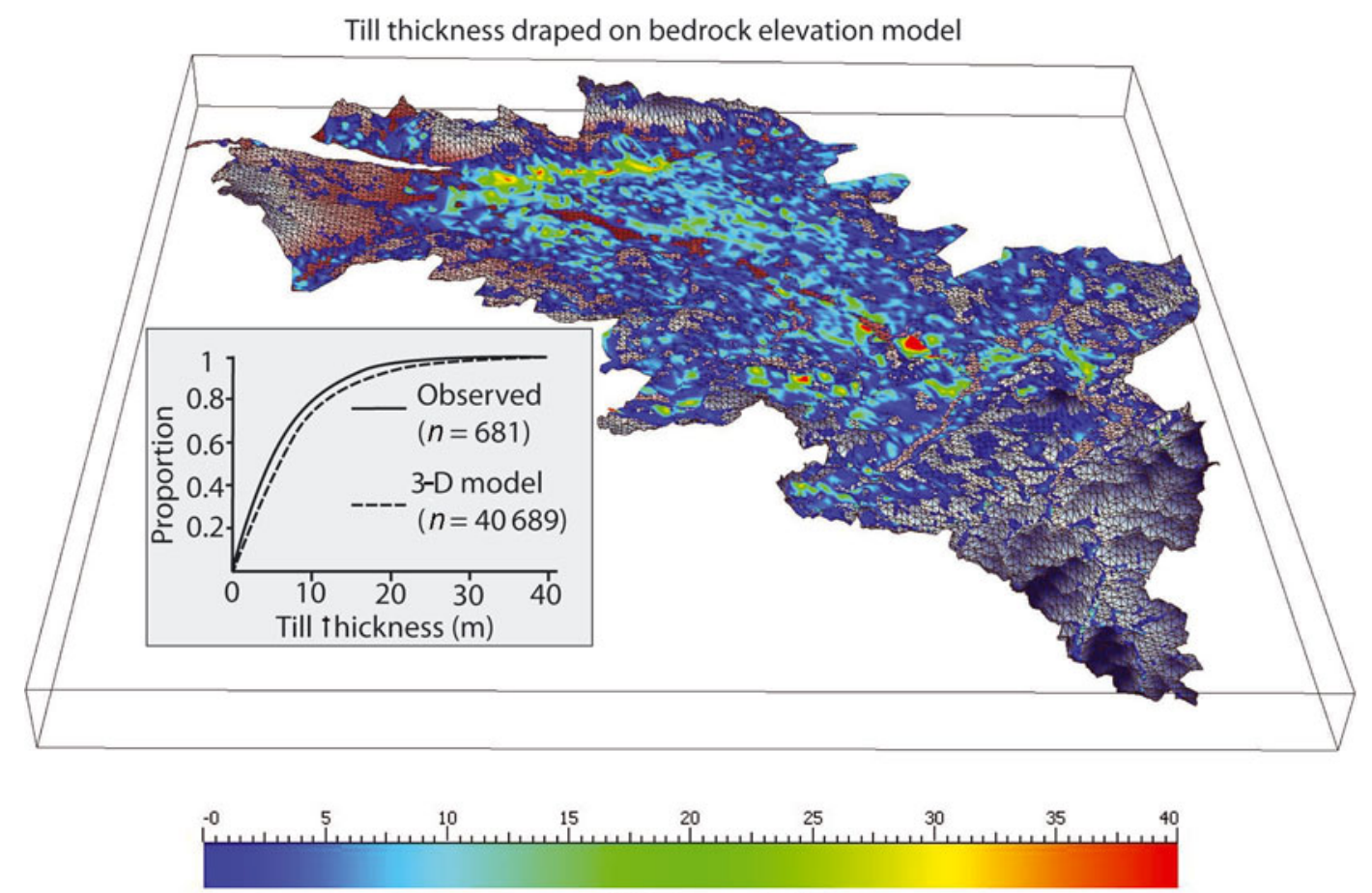

Thickness $(\mathrm{m})$
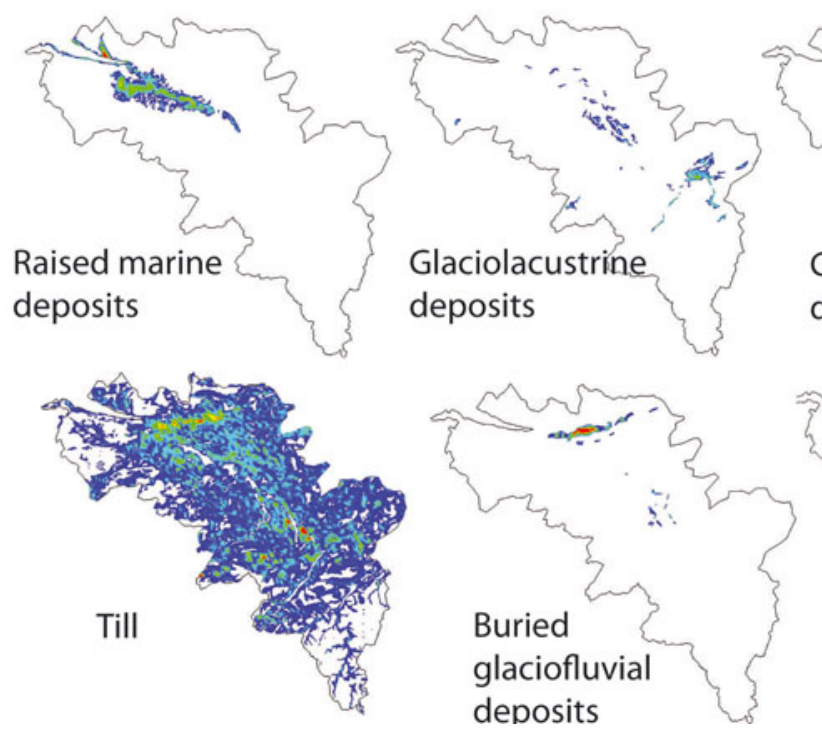

Glaciofluvial deposits

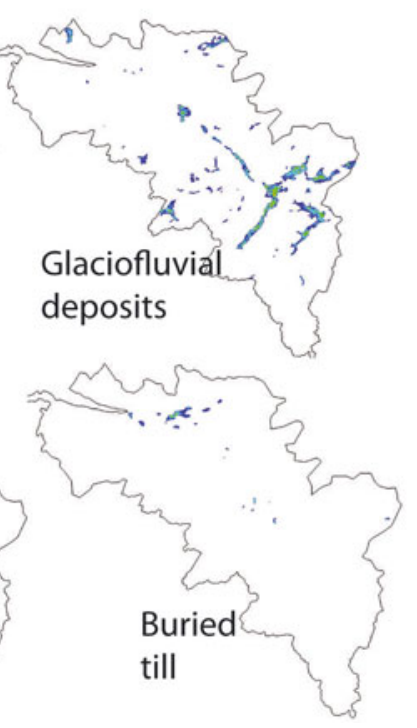

Fig. 9. Thicknesses of selected units. Upper panel shows till thickness draped over bedrock elevation model. Cumulative plots are shown for till thickness revealed from borehole observations, and for till thickness represented in the geological model. The overall thickness distribution in the geological model is consistent with the population of till thickness records from boreholes, demonstrating that the model remains faithful to the observed data.

Ice sheet established; ice divide migration (Fig. $7 b$ and $C$ )

Coalescence of Highland and Southern Upland ice masses allowed an ice divide to develop in the vicinity of the Clyde basin. The transition of the Clyde basin, from being positioned down-ice from the equilibrium line, to being positioned close to the ice divide (Fig. 7a and b) meant that overall sediment erosion was limited, since maximum erosion is thought to occur just up-ice of the equilibrium line (Boulton, 1996). The initial position of the ice divide $\sim 30 \mathrm{~km}$ to the west facilitated eastward flow associated with drumlins of flow set 1 ; these probably formed by local erosion and deposition by a mobile till layer (Boyce and Eyles, 1991). It is not possible to quantify the volumes involved; however, the presence of much thinner till, and in places absence of till, at the eastern boundary of the basin (Fig. 9), suggests that overall sediment loss through continuous bed deformation would have been restricted. Furthermore, preservation of both sediments and landforms from early parts of the glacial cycle (Browne and McMillan, 1989; Finlayson and others, 2010) indicates that basal motion was probably concentrated at or near the icesediment interface, limiting large-scale sediment transport by deformation. Subsequent migration of the ice divide to a position over the Clyde basin (Fig. 7c) would have further limited any sediment mobilization.

Eastward ice flow (Fig. 7c) became more established towards the end of this phase, as deglaciation commenced. It is interesting to note that there is no difference in characteristics of the eastward-oriented drumlins between 

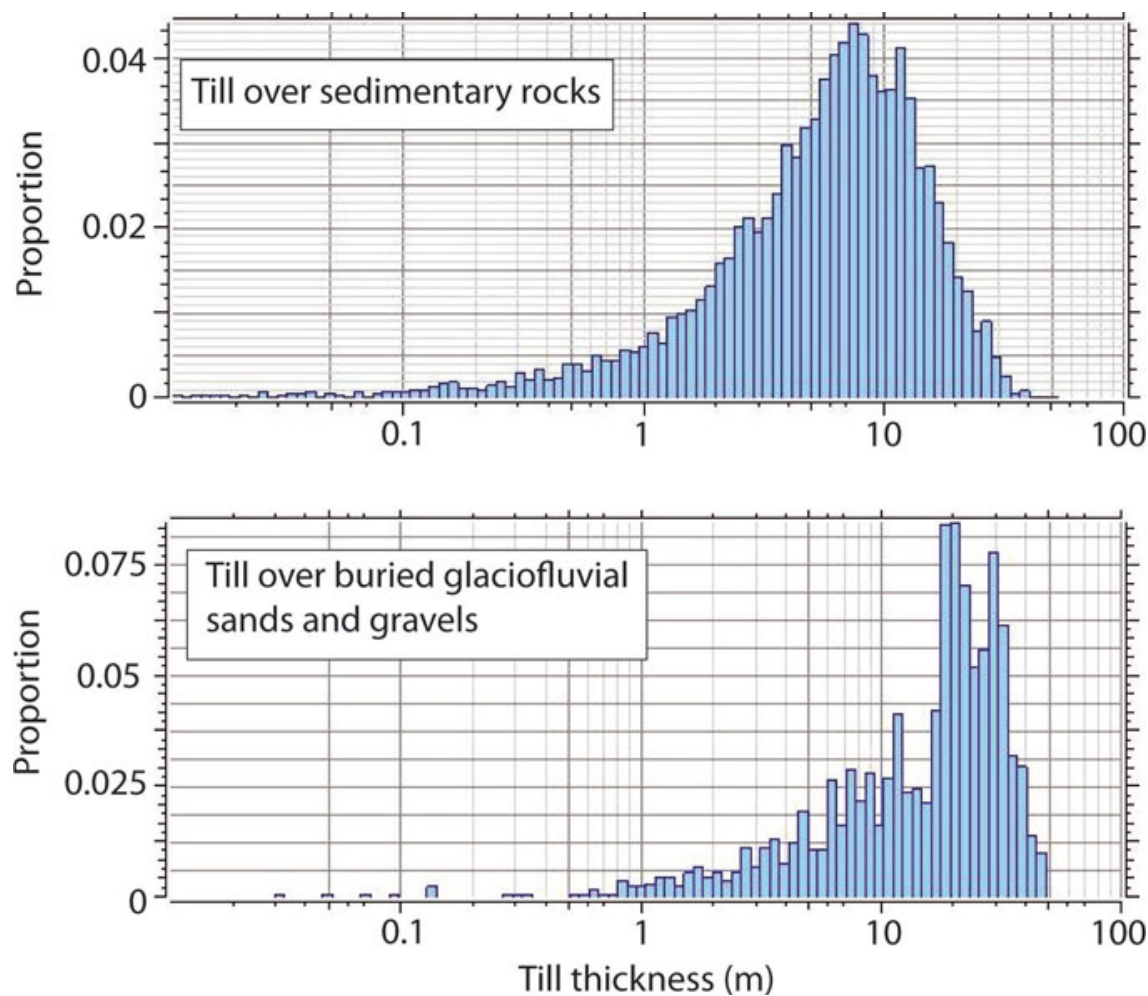

Fig. 10. Histograms of modelled till thickness, in areas where till rests on Carboniferous sedimentary rocks (upper plot) and till rests on glaciofluvial sands and gravels (lower plot).

zones of buried glaciofluvial deposits and adjacent areas (Fig. 12). Lengths ( $L$ ) and elongation ratios (ER) for drumlins overlying buried glaciofluvial deposits $(n=46$, median $L=645 \mathrm{~m}$, median $E R=2.6$ ) and drumlins within a $2 \mathrm{~km}$ zone beyond the margin of the buried glaciofluvial deposits ( $n=81$, median $L=660$, median $E R=2.9$ ) were statistically indistinguishable (Mann-Whitney: $z=0.9, p=0.37$ for $L$; $z=0.91, p=0.36$ for ER). Drumlin elongation has been suggested to be a proxy for relative basal ice-flow velocity (Stokes and Clark, 2001), while basal motion is linked to subglacial water pressure (Paterson, 1994). It is therefore likely that enhanced drainage through the buried glaciofluvial gravelly sands (which were at the land surface prior to advance), was precluded by the thick till preferentially deposited on top (Fig. 10). This would have equalized effective pressures between zones underlain by buried fluvial deposits and adjacent areas. Thus, by focusing thick till sequences over more permeable substrates during advance, the ice sheet may have essentially regulated its basal conditions, facilitating smoother overall basal motion.

Ice-cap uncoupling and deglaciation (Fig. 7d and e) During and following ice-cap uncoupling, glacier flow in the lower Clyde basin was generally towards the southeast, documented by flow set 4 . The drumlins formed during this stage are some of the best preserved in the basin and indicate that till erosion and down-ice deposition were locally occurring at this time. However, for reasons outlined above, it is unlikely that significant volumes of till were lost from the basin by continuous deformation.

The combined volume of the glaciofluvial, glaciolacustrine and glaciodeltaic deposits is $1.08 \mathrm{~km}^{3}$, giving an approximation for the minimum volume of sediment remobilized (predominantly by sub-/proglacial fluvial processes) during ice-sheet withdrawal. The approximation is a minimum since drainage was diverted eastward (via successive overflow cols towards the Firth of Forth) for a period following ice-cap decoupling, which would have resulted in some unaccounted sediment loss, and sediment loss to the Firth of Clyde is not included. These sediments make up $11 \%$ of the total sediment volume in the basin. The duration over which they were deposited only represents the final $2.5 \%$ of the last glacial cycle in the area $(\sim 0.5 \mathrm{ka}$ maximum, based on a synthesis of dates and ice-margin retreat isochrones published in Clark and others (in press)), indicating that transport and deposition by glacial meltwater formed a disproportionately high contribution to the basin sediment budget as the ice margin retreated through the basin. This supports the suggestion by Alley and others

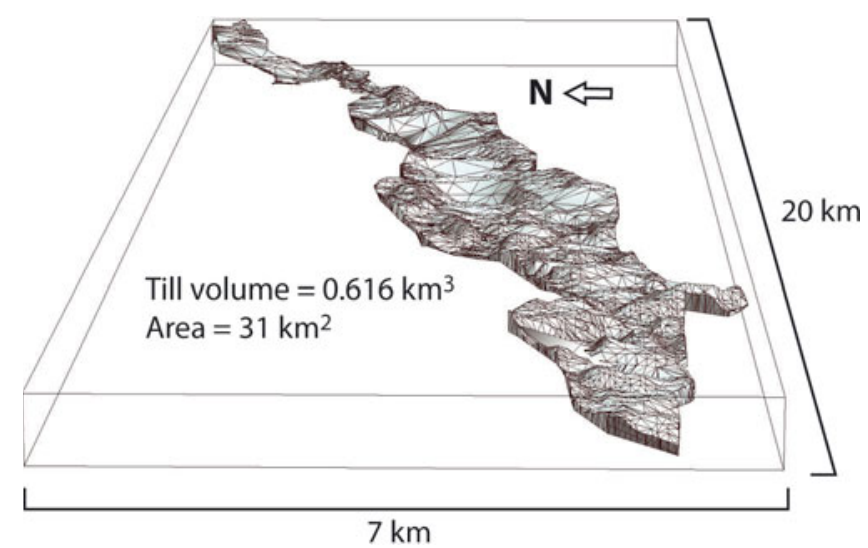

Fig. 11. Till package overlying buried glaciofluvial deposits. This till package is likely to be wholly a product of the last (Late Devensian) glacial cycle. 


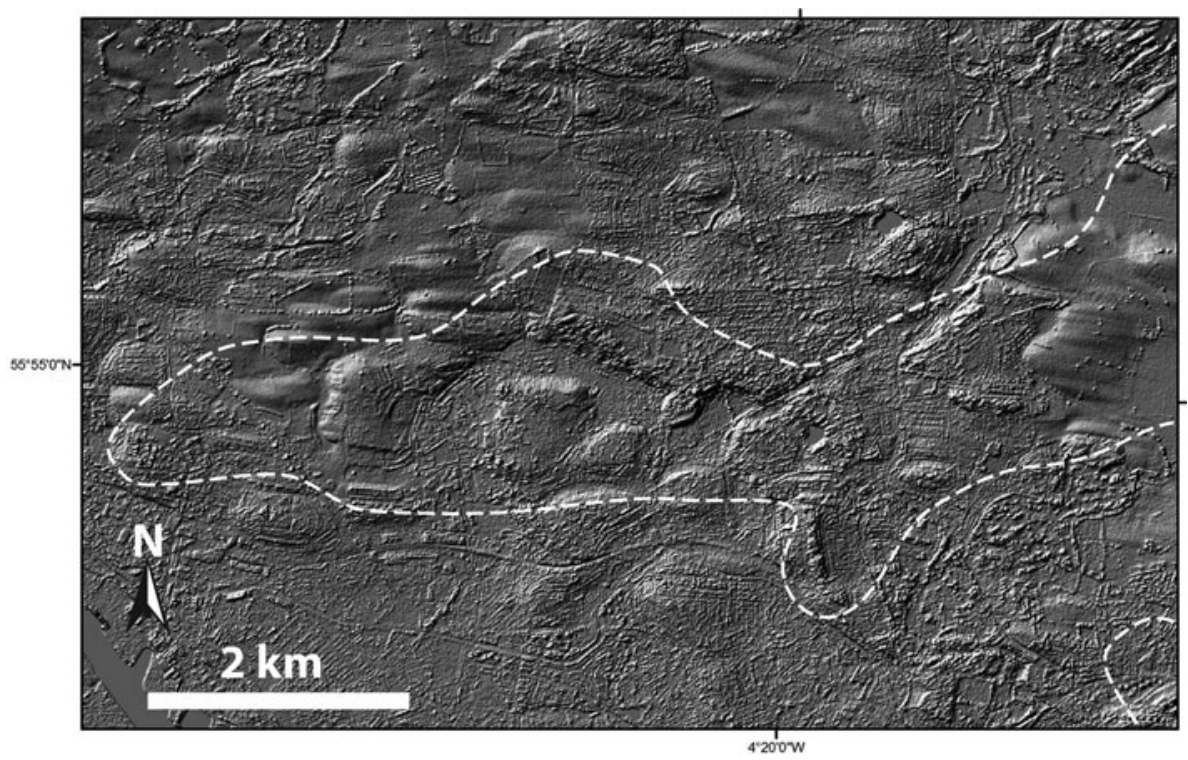

Fig. 12. Drumlinized terrain in north Glasgow. The zone of buried glaciofluvial deposits revealed by the geological model is delimited by the white dashed line. The extent of streamlining is statistically indistinguishable inside and outside this zone of buried glaciofluvial deposits. Hill-shaded digital surface model built from Internet Technologies NEXTMap Britain topographic data.

(1997) that high sediment transport capacities are achieved by subglacial streams in ice-marginal areas, where surface water accessing the bed can promote high water discharges forced by steep head gradients.

\section{WIDER IMPLICATIONS}

The work presented here has attempted to characterize the volume and style of sediment mobilization through the last glacial cycle in the Clyde basin. During that time the basin was occupied by an advancing outlet glacier; it was then positioned under a migrating ice divide, and then once more occupied by an outlet glacier during ice-sheet uncoupling and deglaciation. The data presented here may therefore provide insight into sediment movement in such environments. Although the Clyde basin may have temporarily been located close to the onset zone of fast glacier flow, it was not occupied by an ice stream and is thus not representative of ice-streaming conditions.

Ice-margin advance is shown to have been associated with highly variable spatial and temporal patterns of sediment mobilization. Where ice advanced into relatively soft glaciomarine and glaciolacustrine deposits, sediment fluxes in the marginal area were high. Only rare opportunities exist to study modern glaciers advancing into soft sediments, but, where observed, high fluxes are apparent. For example, the advance of Taku Glacier, Alaska, USA, which is a good modern analogue for Clyde Glacier in its advance stage, has displaced $>100 \mathrm{~m}$ of marine sediment from its bed since 1890 (Nolan and others, 1995). In the case of Clyde Glacier, this high rate of sediment mobilization and redeposition was spatially, and probably temporally, restricted. Reduced basal sediment mobilization took place where relatively soft sediments were absent, or following the exhaustion of soft sediments.

The preferential deposition of thick till over glaciofluvial sediment appears to have acted as a seal, negating the increased drainage capacity of the latter. This suggests that glacier advance and till deposition can alter basal conditions by promoting lower effective pressures. As a result, motion is focused at the ice-till interface, and ice infiltration into the bed by regelation inhibited (Iverson, 2010). In the case of the Clyde basin, this would have favoured preservation of both sediments (Browne and McMillan, 1989) and bedforms (Finlayson and others, 2010) that were produced early in the glacial cycle. However, localized erosion and deposition by a relatively shallow layer of flowing sediment (Boyce and Eyles, 1991; Clark, 2010) must also have occurred in order to carve bedforms during subsequent phases of the glacial cycle.

The Clyde basin is a relatively small area at the ice-sheet scale. Thus, it highlights the spatially variable nature of some bed properties over small areas. The highly variable modelled till thickness (Fig. 9) (mean $7.7 \mathrm{~m}$, standard deviation $7.0 \mathrm{~m}$ ) demonstrates that uniform till sheets (Alley, 1991) do not necessarily occur in all lowland areas.

A considerable volume of sediment in the Clyde basin was remobilized by glacial meltwater during ice-sheet withdrawal, highlighting its role as a geomorphological agent. While the subglacial imprint (e.g. drumlins) often produces the most striking landscape features, ice-margin advance and deglaciation are suggested, in the case of the Clyde basin, to have been key (possibly more important) factors influencing the overall sediment budget during the glacial cycle.

\section{ACKNOWLEDGEMENTS}

I thank David Sugden and Tom Bradwell, and numerous British Geological Survey (BGS) colleagues, for useful discussions; and David, Tom and Clive Auton for their comments on an earlier draft of the manuscript. Helpful comments from two reviewers and the scientific editor, Neil Glasser, improved the paper. This work was carried out as part of the Clyde Urban Super Project (CUSP), a multidisciplinary project that provides geoscience information for urban renewal projects in and around Glasgow. Published with the permission of the Executive Director of the UK Natural Environment Research Council. 


\section{REFERENCES}

Aber JS, Croot DG and Fenton MM (1989) Glaciotectonic landforms and structures. Kluwer Academic Publishers, Dordrecht

Alley RB (1991) Deforming-bed origin for southern Laurentide till sheets? J. Glaciol., 37(125), 67-76

Alley RB, Cuffey KM, Evenson EB, Strasser JC, Lawson DE and Larson G) (1997) How glaciers entrain and transport basal sediment: physical constraints. Quat. Sci. Rev., 16(9), 1017-1038

Bell D (1874) On aspects of Clydesdale during the glacial period. Trans. Geol. Soc. Glasgow, 4A, 63-69

Benn DI, Kristensen L and Gulley JD (2009) Surge propagation constrained by a persistent subglacial conduit, BakaninbreenPaulabreen, Svalbard. Ann. Glaciol., 50(52), 81-86 (doi: 10.3189/172756409789624337)

Boulton GS (1996) Theory of glacial erosion, transport and deposition as a consequence of subglacial sediment deformation. J. Glaciol., 42(140), 43-62

Boulton GS and Clark CD (1990) A highly mobile Laurentide ice sheet revealed by satellite images of glacial lineations. Nature, 346(6287), 813-817

Boulton GS, Dobbie KE and Zatsepin S (2001) Sediment deformation beneath glaciers and its coupling to the subglacial hydraulic system. Quat. Int., 86(1), 3-28

Boyce Jl and Eyles N (1991) Drumlins carved by deforming till streams below the Laurentide ice sheet. Geology, 19(8), 787-790

Boyce JI and Eyles N (2000) Architectural element analysis applied to glacial deposits: internal geometry of a late Pleistocene till sheet, Ontario, Canada. Geol. Soc. Am. Bull., 112(1), 98-118 (doi: 10.1130/0016-7606(2000)112<98:AEAATG>2.0.CO;2)

Bradwell T and 11 others (2008) The northern sector of the last British Ice Sheet: maximum extent and demise. Earth-Sci. Rev. 88(3-4), 207-226 (doi: 10.1016/j.earscirev.2008.01.008)

Brown EJ, Rose J, Coope RG and Lowe JJ (2007) An MIS 3 age organic deposit from Balglass Burn, central Scotland: palaeoenvironmental significance and implications for the timing of the onset of the LGM ice sheet in the vicinity of the British Isles. J. Quat. Sci., 22(3), 295-308 (doi: 10.1002/jqs.1028)

Browne MAE and McMillan AA (1989) Quaternary geology of the Clyde Valley. British Geological Survey, Keyworth (BGS Research Report SA/89/1)

Clark CD (1993) Mega-scale glacial lineations and cross-cutting ice-flow landforms. Earth Surf. Process. Landf., 18(1), 1-29

Clark CD (2010) Emergent drumlins and their clones: from till dilatancy to flow instabilities. J. Glaciol., 56(200), 1011-1025

Clark CD, Hughes ALC, Greenwood SL, Spagnolo M and Ng FSL (2009) Size and shape characteristics of drumlins, derived from a large sample, and associated scaling laws. Quat. Sci. Rev., 28(78), 677-692 (doi: 10.1016/j.quascirev.2008.08.035)

Clark CD, Hughes ALC, Greenwood SL, Jordan C and Sejrup HP (in press) Pattern and timing of retreat of the last British-Irish Ice Sheet. Quat. Sci. Rev. (doi: 10.1016/j.quascirev.2010.07.019)

Clarke GKC (2005) Subglacial processes. Annu. Rev. Earth Planet. Sci., 33, 247-276 (doi: 10.1146/annurev.earth.33.092203. 122621)

Dunlop P, Shannon R, McCabe M, Quinn R and Doyle E (2010) Marine geophysical evidence for ice sheet extension and recession on the Malin Shelf: New evidence for the western limits of the British Irish Ice Sheet. Mar. Geol., 276(1-4), 86-99 (doi: 10.1016/j.margeo.2010.07.010)

Eyles N and McCabe AM (1989) The Late Devensian ( $<22,000$ YBP) Irish Sea basin: the sedimentary record of a collapsed ice sheet margin. Quat. Sci. Rev., 8(4), 307-351

Finlayson A, Merritt J, Browne M, Merritt J, McMillan A and Whitbread K (2010) Ice sheet advance, dynamics, and decay configurations: evidence from west central Scotland. Quat. Sci. Rev., 29(7-8), 969-988 (doi: 10.1016/j.quascirev.2009.12.016)

Green PJ and Sibson R (1978) Computing Dirichlet tessellations in the plane. Comput. J., 21(2), 168-173 (doi: 10.1093/comjnl/ 21.2.168)
Hubbard A and 7 others (2009) Dynamic cycles, ice streams and their impact on the extent, chronology and deglaciation of the British-Irish ice sheet. Quat. Sci. Rev., 28(7-8), 758-776 (doi: 0.1016/j.quascirev.2008.12.026)

Hughes ALC, Clark CD and Jordan CJ (2010) Subglacial bedforms of the last British Ice Sheet. J. Maps, 2010, 543-563 (doi: 10.4113/jom.2010.1111)

Iverson NR (2010) Shear resistance and continuity of subglacial till: hydrology rules. J. Glaciol., 56(200), 1104-1114

Jacobi RM, Rose J, MacLeod A and Higham TFG (2009) Revised radiocarbon ages on woolly rhinoceros (Coelodonta antiquitatis) from western central Scotland: significance for timing the extinction of woolly rhinoceros in Britain and the onset of the LGM in central Scotland. Quat. Sci. Rev., 28(25-26), 2551-2556 (doi: 10.1016/j.quascirev.2009.08.010)

Kearsey T and 6 others (2011) Comparing and fusing deterministic and stochastic geological models: an example from the City of Glasgow, UK. In Model Fusion Conference, 28-29 November 2011, London, UK, abstracts. British Geological Survey, Natural Environment Research Council (http://nora.nerc.ac.uk/16001/)

Kessler H, Mathers S and Sobisch H-G (2009) The capture and dissemination of integrated 3D geospatial knowledge at the British Geological Survey using GSI3D software and methodology. Comput. Geosci., 35(6), 1311-1321 (doi: 10.1016/ j.cageo.2008.04.005)

Kleman J, Hättestrand C, Borgström I and Stroeven A (1997) Fennoscandian palaeoglaciology reconstructed using a glacial geological inversion model. J. Glaciol., 43(144), 283-299

Kleman J, Hättestrand C, Stroeven A, Jansson KN, De Angelis H and Borgstrom I (2006) Reconstruction of paleo-ice sheets inversion of their glacial geomorphological record. In Knight PG ed. Glacier science and environmental change. Blackwell, Oxford, 192-198

Knight J and McCabe AM (1997) Drumlin evolution and ice sheet oscillations along the NE Atlantic margin, Donegal Bay, western Ireland. Sediment. Geol., 111(1-4), 57-72

Kopp RE, Simons FJ, Mitrovica JX, Maloof AC and Oppenheimer M (2009) Probabilistic assessment of sea level during the last interglacial stage. Nature, 462(7275), 863-867 (doi: 10.1038/ nature08686)

Lawley R and Garcia-Bajo M (2009) The national superficial deposit thickness model (Version 5). British Geological Survey, Nottingham (BGS Report OR/09/049)

Lee JR, Busschers FS and Sejrup HP (in press) Pre-Weichselian Quaternary glaciations of the British Isles, The Netherlands, Norway and adjacent marine areas south of $68^{\circ} \mathrm{N}$ : implications for long-term ice sheet development in northern Europe. Quat. Sci. Rev. (doi: 10.1016/j.quascirev.2010.02.027)

Leysinger Vieli GJMC and Gudmundsson GH (2010) A numerical study of glacier advance over deforming till. Cryosphere, 4(3), 359-372 (doi: 10.5194/tc-4-359-2010)

McMillan AA and Browne MAE (1983) Glaciotectonic structures at Bellshill, East end of Glasgow. Quat. Newslett. 40, 1-6

Menzies J (1976) The glacial geomorphology of Glasgow with particular refernce to the drumlins ( $\mathrm{PhD}$ thesis, University of Edinburgh)

Menzies J (1981) Investigations into the Quaternary deposits and bedrock topography of central Glasgow. Scot. J. Geol., 17(3), 155-168 (doi: 10.1144/sjg17030155)

Meriano M and Eyles N (2009) Quantitative assessment of the hydraulic role of subglaciofluvial interbeds in promoting deposition of deformation till (Northern Till, Ontario). Quat. Sci. Rev., 28(7-8), 608-620 (doi: 10.1016/j.quascirev. 2008.08.034)

Motyka RJ, Truffer M, Kruiger EM and Bucki AK (2006) Rapid erosion of soft sediments by tidewater glacier advance: Taku Glacier, Alaska, USA. Geophys. Res. Lett., 33(24), L24504 (10.1029/2006GL028467)

Nolan M, Motyka RJ, Echelmeyer K and Trabant DC (1995) Icethickness measurements of Taku Glacier, Alaska, U.S.A., and 
their relevance to its recent behavior. J. Glaciol., 41(139), 541-553

Ó Cofaigh C, Evans DJA and Hiemstra JF (2011) Formation of a stratified subglacial 'till' assemblage by ice-marginal thrusting and glacier overriding. Boreas, 40(1), 1-14 (doi: 10.1111/ j.1502-3885.2010.00177.x)

Paterson IB, McAdam AD and MacPherson KAT (1998) Geology of the Hamilton district: memoir for 1:50,000 geological sheet $23 W$ (Scotland). Stationery Office, London

Paterson WSB (1994) The physics of glaciers, 3rd edn. Elsevier, Oxford

Peacock JD (1971) Marine shell radiocarbon dates and the chronology of deglaciation in western Scotland. Nature, 230(10), 43-45 (doi: 10.1038/physci230043a0)

Peacock JD (2003) Late Quaternary sea level change and raised marine deposits of the western Highland Boundary: a) the deglaciation of the lower Clyde valley: a brief review. In Evans DJA ed. The Quaternary of the western Highland Boundary: field guide. Quaternary Research Association, London, 30-41

Piotrowski JA, Mickelson DM, Tulaczyk S, Krzyszkowski D and Junge FW (2001) Were deforming subglacial beds beneath past ice sheets really widespread? Quat. Int., 86(1), 139-150

Price RJ (1975) The glaciation of west central Scotland - a review. Scot. Geogr. Mag., 91(3), 134-145 (doi: 10.1080/ 00369227508736314)

Rose J (1981) Field guide to the Quaternary geology of the south eastern part of the Loch Lomond basin. In Proceedings of the Geological Society of Glasgow, 122/123, 12-28

Rose J (2003) Geilston: Lateglacial and Holocene sea level change. In Evans DJA ed. The Quaternary of the western Highland Boundary: field guide. Quaternary Research Association, London, 190-199

Rose J and Letzer JM (1977) Superimposed drumlins. J. Glaciol., 18(80), 471-480

Rose J and Smith MJ (2008) Glacial geomorphological maps of the Glasgow region, western central Scotland. J. Maps, 2008, Special issue 6, 399-416 (doi: 10.4113/jom.2008.1040)
Rose J, Lowe JJ and Switsur R (1988) A radiocarbon date on plant detritus beneath till from the type area of the Loch Lomond Readvance. Scot. J. Geol., 24(2), 113-124 (doi: 10.1144/ sjg24020113)

Scourse JD and 7 others (2009) Growth, dynamics and deglaciation of the last British-Irish ice sheet: the deep-sea ice-rafted detritus record. Quat. Sci. Rev., 28(27-28), 3066-3084 (doi: 10.1016/ j.quascirev.2009.08.009)

Smith AM and 6 others (2007) Rapid erosion, drumlin formation and changing hydrology beneath an Antarctic ice stream. Geology, 35(2), 127-130 (doi: 10.1130/G23036A.1)

Smith MJ and Clark CD (2005) Methods for the visualization of digital elevation models for landform mapping. Earth Surf. Process. Landf., 30(7), 885-900 (doi: 10.1002/esp.1210)

Stokes CR and Clark CD (2001) Palaeo-ice streams. Quat. Sci. Rev., 20(13), 1437-1457

Stokes CR, Clark CD and Storrar R (2009) Major changes in ice stream dynamics during deglaciation of the north-western margin of the Laurentide Ice Sheet. Quat. Sci. Rev., 28(7-8), 721-738 (doi: 10.1016/j.quascirev.2008.07.019)

Stokes CR, Spagnolo M and Clark CD (2011) The composition and internal structure of drumlins: Complexity, commonality, and implications for a unifying theory of their formation. Earth-Sci. Rev., 107(3-4), 398-422 (doi: 10.1016/j.earscirev.2011.05.001)

Sugden DE and John BS (1976) Glaciers and landscape; a geomorphological approach. Edward Arnold, London

Sutherland DG and Gordon JE (1993) Western central lowlands. Introduction. In Gordon JE and Sutherland DG eds. The Quaternary of Scotland. Chapman \& Hall, London, 535-556 (Geological Conservation Review Series 6)

Thomas GSP and Montague E (1997) The morphology, stratigraphy and sedimentology of the Carstairs Esker, Scotland, U.K. Quat. Sci. Rev., 16(7), 661-674

Thomason JF and Iverson NR (2009) Deformation of the Batestown till of the Lake Michigan Lobe, Laurentide ice sheet. J. Glaciol., 55(189), 131-146 (doi: 10.3189/002214309788608877)

MS received 6 October 2011 and accepted in revised form 14 January 2012 